\title{
Accession to Tuberculosis Treatment: Individual and Social Vulnerability Elements

\begin{abstract}
Rayrla Cristina de Abreu Temoteo ${ }^{1,2}$, Fernanda Darliane Tavares de Luna1, Sheylla Nadjane Batista Lacerda², Luiz Carlos de Abreu ${ }^{3}$, Fernando Luiz Affonso Fonseca ${ }^{3}$, Edwirde Luiz Silva1, Maria Rita Bertolozzi ${ }^{4}$, Tânia Maria Ribeiro Monteiro de Figueiredo
\end{abstract}

\section{Abstract}

Introduction: Tuberculosis (TB) remains as a major public health problem, being the second infectious disease to cause death all over the world. The Directly Observed Treatment (DOT) is one of the recommended strategies to control this disease. The accession in this mode of treatment is integrated into the Tuberculosis Control Program $(P C T)$, this program also provide socio-economic incentives as the distribution of food baskets, bus passes and breakfast. Moreover, public policies for social protection help both family development and social vulnerability. Tuberculosis is still associated with social exclusion and marginalization of the population subjected to poor living conditions and limited access to public services.

Objective: Analyze the potential accession to tuberculosis treatment related to individual and social vulnerability aspects.

Methods: Cross-sectional, qualitative study, conducted with 39 individuals diagnosed with tuberculosis and in treatment for at least 30 days in the city of Campina Grande, Paraiba, Brazil. 20 markers were used as analysis units, with the possibility of score responses from one to three. The lower scores indicate lower potential of adherence to treatment, while the highest ones express greater potential accession.

Results: xx markers that were more related to score one and indicated lower potential adherence to tuberculosis treatment were: tuberculosis impact on labor; conception of health-disease causality and work process (employment status). In contrast, markers that were more closely related to the score three that resonate with greater
1 Universidade Estadual da Paraíba, Paraíba, PB, Brazil.

2 Faculdade Santa Maria, Paraíba, PB, Brazil.

3 Faculdade de Medicina do ABC, Santo André, SP, Brazil.

4 UUniversidade de São Paulo, São Paulo, SP, Brazil.

Contact information:

Rayrla Cristina de Abreu Temoteo.

”rayrlacz@hotmail.com 
adherence capability to tuberculosis treatment were: Drug use, life (housing situation) and treatment difficulties in the disease course.

Conclusion: The instrument used allowed the presentation of low potential markers for adherence to tuberculosis treatment. Therefore, it is recommended the use of markers in Primary Health Care for monitoring adherence to tuberculosis treatment.

\section{Keywords}

Patient Adherence; Treatment; Tuberculosis; Vulnerability.

\section{Introduction}

Tuberculosis (TB) is a major disease faced in the world, given its association with social exclusion and population marginalization subjected to poor living conditions, such as poor housing, malnutrition and limited access to public services. Therefore, strategic actions have been implemented by the Primary Health Care (PHC), strengthened by decentralization, with the primary aim of improving access and promoting adherence to TB treatment [1].

One of the strategies used is the short term Directly Observed Treatment (DOT); designation that comes from English Directly Observed Therapy Short-Course (DOTS), which consists of direct administration of the drug by a second person who observes and records every dose. However, this strategy considers a care management technology to control TB that prioritizes, in addition to drug treatment, other activities such as investigation of sociocultural and economic profiles of the patient and his family, and monitoring the health of the treated individual. This approach aims, primarily, to increase the accession in the treatment, discover more infection sources and enhance healing, reducing the risk of community transmission [2-3].

In the TB treatment accession, several aspects that provide peculiarities and specifics must be considered, not just as a behavior and attitudes results and not reduced to the singular aspect of the question, but as a search for potential identification, that help the treatment realization in a more appropriately way. These capabilities consider plans that concern the design of the individual health-disease with the disease; that refers to the social place occupied by the individual and that attends to the health production process.

The conception of the health-disease process of the individual diagnosed with TB relates to the interpretation of the patient's experience in the process, which makes his daily life conducted in a more actively or passively way, with his broad understanding, enabling transformation and non-conformism, with responsibility of the team in the conduct of health interventions.

The patient's integration into society incorporates access to work and to all the elements that make up life in society, which enable the maintenance of life and don't allow the wearing out of the same4. Therefore, the accession is an important factor for the TB treatment outcome. From this, the patient can be led to the abandonment or to the cure [7]. A high accession rate produces not only an expansion in the cure percentage, but is directly related to the decrease in contamination and reduce the emergence of multidrug-resistant strains [3, 5-6].

The factors that increase adherence to TB treatment are: the presence of a multidisciplinary team in TB program, family support, the desire to return to social life activities (such as work and familiar meetings), access and incentives dispensed by health services, the established bond between professionals and users, as well as the supervision strategy of taking the medication [7-8]. 
However, exposure and control of diseases such as TB result from individual aspects and collective contexts or conditions that produce greater susceptibility to diseases and, simultaneously, the possibility and resources for solving them. That's the idea of vulnerability, which expresses well the potential of becoming and not becoming ill, as well as the confrontation, related to any individual [4].

The vulnerability aspects may appear in three interdependent dimensions (individual, social and programmatic). Individual vulnerability is determined by cognitive (information access, recognizing the sensitivity and effectiveness of forms of prevention), behavioral (willingness and ability to change behaviors that define susceptibility) and social (access to resources and capacity to adopt behaviors for protection) conditions, and social vulnerability integrates the features of social space, existing social norms, institutional norms, gender relations and inequities. The interpretation of these aspects is required for the correct understanding of adherence to disease treatment [4, 9-11].

In this perspective, the research aimed to investigate the potential of adhesion to tuberculosis treatment related to aspects of individual and social vulnerability, expressed by scores of adhesion markers in the city of Campina Grande, Paraíba, Brazil. Campina Grande is a priority city for TB control because it meets the criteria of Technical Note $N^{0} .15$ of the Ministry of Health [3].

\section{Method}

A cross-sectional and quantitative study. 20 makers were used for analysis, selected for expressing elements of individual and social vulnerabilities to adherence of tuberculosis (TB) treatment. The markers are relative to dimensions contained in the data collection tool: social condition, vulnerable contexts, health-disease process and treatment.

The adopted concept of vulnerability is from Ayres [11], considering the following aspects for patients with tuberculosis: individual dimension, which is addressed through concomitant diseases identification, functional disability, perceived social support and health perception; the social dimension, which is addressed through the variables related to age, education, occupation and income; programmatic dimension, which is addressed through the single Health System (SHS) indexes-dependence and social vulnerability of the patient, access to and use of health services.

The data from this study are from the multicenter research project entitled "Adherence to tuberculosis treatment: implementation markers for monitoring patients" whose goal is to implement a tool that allows to detect vulnerable elements in adherence to tuberculosis treatment, within Primary Health Care (PHC) in two regions of Brazil (Northeast and Southeast) $[12,13]$.

The Northeast region was represented by the city of Campina Grande, in the state of Paraíba, Brazil. Campina Grande is the second most populous city in the state, with approximately 400, 000 inhabitants, distant $133 \mathrm{~km}$ from state capital João Pessoa [14]. It features 94 Teams of Health distributed family at 88 Basic Health Units, corresponding to coverage of approximately $85 \%$, favoring the decentralization of actions into the realm of PHC [13].

The instrument used, validated for application in $\mathrm{PHC}$ is made up of variables regarding the characterization of the participants, the socioeconomic and demographic indicators, the health-disease process and the treatment outcome, as well as accession of 32 markers, distributed in the social conditions, vulnerable contexts, the health-disease process, treatment and health services dimensions [12].

For each marker there are three possible answers related to the scores one, two or three. The lowest scores indicate lower potential for treatment accession, while the highest express greater potential for the accession. Table 1 shows the selected markers with their respective choices of answers and scores. 
Table 1. Individual and social vulnerability markers to accession to tuberculosis treatment. Campina Grande, Paraíba, Brazil, in 2015.

\begin{tabular}{|c|c|c|}
\hline Marker & Answers & Scores \\
\hline \multicolumn{3}{|c|}{ Dimension 1 - Social conditions } \\
\hline \multirow{3}{*}{ Education } & Cannot read and write & 1 \\
\hline & Can read, but not write & 2 \\
\hline & Can read and write & 3 \\
\hline \multirow{3}{*}{$\begin{array}{l}\text { Work } \\
\text { (employment } \\
\text { status) }\end{array}$} & Has no work & 1 \\
\hline & Not a steady job & 2 \\
\hline & It has a steady work & 3 \\
\hline \multirow{3}{*}{ Life $^{1}$} & $\begin{array}{l}\text { Person lives in the street/hostel } \\
\text { situation }\end{array}$ & 1 \\
\hline & Living alone & 2 \\
\hline & Lives with others & 3 \\
\hline \multirow{3}{*}{ Faith ${ }^{2}$} & Not attending & 1 \\
\hline & Attends sporadically & 2 \\
\hline & Always attends & 3 \\
\hline \multicolumn{3}{|c|}{ Dimension 2 - Vulnerable Contexts } \\
\hline \multirow{3}{*}{ Drinking } & Consumes alcohol and gets drunk & 1 \\
\hline & $\begin{array}{l}\text { Consumes alcohol and does not get } \\
\text { drunk }\end{array}$ & 2 \\
\hline & Does not consumes alcohol & 3 \\
\hline \multirow{3}{*}{$\begin{array}{l}\text { Smoke } \\
\text { Consumption }\end{array}$} & Smokes everyday & 1 \\
\hline & Sometimes & 2 \\
\hline & Does not smoke & 3 \\
\hline \multirow{3}{*}{ Use of drugs } & Yes, everyday & 1 \\
\hline & $\begin{array}{l}\text { Sometimes/stopped due to the } \\
\text { treatment }\end{array}$ & 2 \\
\hline & Does not use & 3 \\
\hline \multicolumn{3}{|c|}{ Dimension 3 - Health-disease process } \\
\hline \multirow{3}{*}{$\begin{array}{l}\text { Associated } \\
\text { disease }\end{array}$} & $\begin{array}{l}\text { Has disease associated to } \\
\text { tuberculosis and uses other } \\
\text { medications }\end{array}$ & 1 \\
\hline & $\begin{array}{l}\text { Has a disease associated with } \\
\text { tuberculosis, but does not use other } \\
\text { medication }\end{array}$ & 2 \\
\hline & $\begin{array}{l}\text { Does not has associated with } \\
\text { tuberculosis disease }\end{array}$ & 3 \\
\hline \multirow{3}{*}{$\begin{array}{l}\text { Causality } \\
\text { of health- } \\
\text { disease } \\
\text { process }\end{array}$} & $\begin{array}{l}\text { Unawareness of the cause of the } \\
\text { disease }\end{array}$ & 1 \\
\hline & $\begin{array}{l}\text { Associates the disease to the } \\
\text { etiological agent }\end{array}$ & 2 \\
\hline & $\begin{array}{l}\text { Associates the disease to the agent } \\
\text { and to the elements of life and } \\
\text { work }\end{array}$ & 3 \\
\hline
\end{tabular}

\begin{tabular}{|c|c|c|}
\hline Marker & Answers & Scores \\
\hline \multicolumn{3}{|c|}{ Dimension 3 - Health-disease process } \\
\hline \multirow{3}{*}{$\begin{array}{l}\text { Knowledge } \\
\text { of the disease }\end{array}$} & Unawareness of the disease & 1 \\
\hline & $\begin{array}{l}\text { Knew the disease (friends/ } \\
\text { neighbors/nobody) }\end{array}$ & 2 \\
\hline & $\begin{array}{l}\text { Knew the disease, which affected } \\
\text { family }\end{array}$ & 3 \\
\hline \multirow{3}{*}{$\begin{array}{l}\text { patient's } \\
\text { reaction to } \\
\text { the diagnosis }\end{array}$} & Apparently negative reaction & 1 \\
\hline & Seemingly indifferent reaction & 2 \\
\hline & Apparently positive reaction & 3 \\
\hline \multirow{3}{*}{$\begin{array}{l}\text { Informed } \\
\text { about the } \\
\text { disease }\end{array}$} & $\begin{array}{l}\text { Did not inform anyone about the } \\
\text { disease }\end{array}$ & 1 \\
\hline & Family informed about the disease & 2 \\
\hline & $\begin{array}{l}\text { Reported family and others (friends } \\
\text { and co-workers) }\end{array}$ & 3 \\
\hline \multirow{3}{*}{$\begin{array}{l}\text { Impact of } \\
\text { tuberculosis } \\
\text { on life }\end{array}$} & $\begin{array}{l}\text { The disease caused negative impact } \\
\text { on life }\end{array}$ & 1 \\
\hline & $\begin{array}{l}\text { The disease sometimes causes } \\
\text { negative impact on life }\end{array}$ & 2 \\
\hline & $\begin{array}{l}\text { The disease did not cause negative } \\
\text { impact on life }\end{array}$ & 3 \\
\hline \multirow{3}{*}{$\begin{array}{l}\text { Impact of } \\
\text { tuberculosis } \\
\text { on work }\end{array}$} & $\begin{array}{l}\text { Caused negative impact on work } \\
\text { activities }\end{array}$ & 1 \\
\hline & $\begin{array}{l}\text { Sometimes has a negative impact } \\
\text { on work }\end{array}$ & 2 \\
\hline & $\begin{array}{l}\text { It did not cause negative impact on } \\
\text { work }\end{array}$ & 3 \\
\hline \multicolumn{3}{|c|}{ Dimension 4 - Treatment } \\
\hline \multirow{3}{*}{$\begin{array}{l}\text { Difficulties in } \\
\text { the treatment } \\
\text { with drugs }\end{array}$} & $\begin{array}{l}\text { Always presents difficulties in the } \\
\text { intake of drugs }\end{array}$ & 1 \\
\hline & Sometimes presents difficulties & 2 \\
\hline & Never presents difficulties & 3 \\
\hline \multirow{3}{*}{$\begin{array}{l}\text { Difficulties in } \\
\text { treatment in } \\
\text { the course of } \\
\text { the disease }\end{array}$} & $\begin{array}{l}\text { Displays deterioration even after } \\
\text { initiation of treatment }\end{array}$ & 1 \\
\hline & $\begin{array}{l}\text { Nothing has changed even with } \\
\text { treatment }\end{array}$ & 2 \\
\hline & $\begin{array}{l}\text { It shows improvement after } \\
\text { initiation of treatment }\end{array}$ & 3 \\
\hline \multirow{3}{*}{$\begin{array}{l}\text { Difficulties } \\
\text { in treatment } \\
\text { in relation to } \\
\text { family living }\end{array}$} & $\begin{array}{l}\text { Family does not support treatment/ } \\
\text { or does not have family }\end{array}$ & 1 \\
\hline & $\begin{array}{l}\text { Family members sometimes support } \\
\text { the treatment }\end{array}$ & 2 \\
\hline & Family always support the treatment & 3 \\
\hline \multirow{3}{*}{$\begin{array}{l}\text { Difficulties } \\
\text { in treatment } \\
\text { in relation to } \\
\text { the support } \\
\text { at work }{ }^{3}\end{array}$} & $\begin{array}{l}\text { There is no support at work and/or } \\
\text { did not mention is sick }\end{array}$ & 1 \\
\hline & $\begin{array}{l}\text { Some colleagues/heads support the } \\
\text { treatment }\end{array}$ & 2 \\
\hline & $\begin{array}{l}\text { Colleagues/management always } \\
\text { support the treatment }\end{array}$ & 3 \\
\hline
\end{tabular}




\begin{tabular}{|c|c|c|}
\hline Marker & Answers & Scores \\
\hline \multicolumn{3}{|c|}{ Dimension 4 - Treatment } \\
\hline \multirow{3}{*}{$\begin{array}{l}\text { Desire to } \\
\text { withdrawal } \\
\text { from the } \\
\text { continuity of } \\
\text { care }\end{array}$} & $\begin{array}{l}\text { Desire for withdrawal from the } \\
\text { continuity of care }\end{array}$ & 1 \\
\hline & Thought about giving up treatment & 2 \\
\hline & $\begin{array}{l}\text { It shows no desire to give up the } \\
\text { treatment }\end{array}$ & 3 \\
\hline \multirow{3}{*}{$\begin{array}{l}\text { Ability to } \\
\text { formulate life } \\
\text { projects to be } \\
\text { implemented } \\
\text { after } \\
\text { treatment }\end{array}$} & $\begin{array}{l}\text { It does not appear to provide } \\
\text { motivation }\end{array}$ & 1 \\
\hline & $\begin{array}{l}\text { Motivation related to the need to } \\
\text { improve health }\end{array}$ & 2 \\
\hline & $\begin{array}{l}\text { Motivation related to the need } \\
\text { to improve health and for other } \\
\text { reasons: children, work, other }\end{array}$ & 3 \\
\hline \multicolumn{3}{|c|}{1 Situation of housing. } \\
\hline \multicolumn{3}{|c|}{${ }^{2}$ Refers to attend or not a religious institution. } \\
\hline & ${ }^{3}$ Only people who work answered this & \\
\hline
\end{tabular}

By using adhesion markers to TB treatment, the possibility of signalize, qualitatively, elements that express vulnerability to the tuberculosis treatment adherence so that the appropriate interventions that favorate the treatment can be dispensed.

To compose the study population, 53 patients diagnosed with TB that held the treatment for at least 30 days were considered, those were diagnosed from September 2014 to February 2015. Those patients had 18 years old or more. People deprived of liberty, in treatment away from home and that had not preserved understanding capacity were excluded.

As all components of the population could participate, it was adopted a census type sampling. However, eight were under 18, two inmates, one had not preserved understanding capacity, one did not live in the city of Campina Grande, Paraíba, Brazil, one was hospitalized at the time of data collection and one refused to participate, so the total of participants was 39 .

Data were collected in March 2015, through a structured interview that could happen in the health service where the participant was under TB treatment (Tuberculosis in Reference Service) while waiting for medical consultation follow-up, or even in his home, according to the patient's convenience.

Data was entered into a Microsoft Office Excel 2003 spreadsheet, and it was proceeded to a descriptive analysis by the absolute and relative frequencies calculation, referring to scores of 20 selected markers. It also used the summary of the five numbers and box plots (a compact graphical summary procedure that transmits information about the central tendency, symmetry, asymmetry, variation, minimum and maximum values and outliers) to allow a better view of the dispersion scores.

The research project was approved by the Research Ethics Committee (CEP) of the State University of Paraíba, Brazil (UEPB) under the CAAE Protocol n 34560114.7.2001.5187.

\section{Results}

In the selected markers, "Tuberculosis (TB) impact on the job" obtained as most frequent answer score one, while the marker that obtained as more expressive answer score three, which indicates greater potential for accession, was "Drug use".

They were also impressive the markers "notion on the causality of health-disease process" and "Work (employment status)" with score one significant frequencies. The markers "Life (housing situation)" and "Treatment difficulties in the course of the disease" presented relevant score of three frequencies, which are seen in Table 2.

The descriptive analyzes presented in Table 2 and Figure 1 compare the three identified score groups. The boxplot type graphics have a complete summary of simple data. Each score is represented by a box that indicates where $50 \%$ of the observations are.

By analyzing the quantitative data of answers by each score, it is observed that the score number three shows median of $43.6 \%$ (which equivalent to 17 participants), that is what most stands out for bringing together almost $93 \%$ of patients 
Table 2. Individual and social vulnerability markers distribution to treatment adherence in relation to the scores. Campina Grande, Paraíba, Brazil, in 2015.

\begin{tabular}{|c|c|c|c|c|c|c|c|}
\hline \multirow{3}{*}{ Dimensions/Bookmark } & \multirow{3}{*}{$\mathbf{N}$} & \multicolumn{6}{|c|}{ Scores } \\
\hline & & \multicolumn{2}{|c|}{1} & \multicolumn{2}{|c|}{2} & \multicolumn{2}{|c|}{3} \\
\hline & & $\mathrm{N}$ & $\%$ & $\mathrm{~N}$ & $\%$ & $\mathrm{~N}$ & $\%$ \\
\hline \multicolumn{8}{|l|}{ Dimension 1 - Social conditions } \\
\hline Education & 39 & 13 & 33.3 & 1 & 2.6 & 25 & 64.1 \\
\hline Work (employment status) & 39 & 25 & 64.1 & 6 & 15.4 & 8 & 20.5 \\
\hline Life (housing situation) & 39 & 1 & 2.6 & 3 & 7.7 & 35 & 89.7 \\
\hline Faith & 39 & 17 & 43.6 & 12 & 30.7 & 10 & 25.7 \\
\hline \multicolumn{8}{|l|}{ Dimension 2 - Vulnerable Contexts } \\
\hline Alcohol consumption & 39 & 4 & 10.3 & 3 & 7.7 & 32 & 82 \\
\hline Smoke Consumption & 39 & 6 & 15.4 & 2 & 5.1 & 31 & 79.5 \\
\hline Drug use & 39 & 1 & 2.6 & 2 & 5.1 & 36 & 92.3 \\
\hline \multicolumn{8}{|l|}{ Dimension 3 - Health-disease process } \\
\hline Associated disease & 39 & 18 & 46.1 & 1 & 2.6 & 20 & 51.3 \\
\hline Conception of causality of the health-disease process & 39 & 27 & 69.2 & 2 & 5.1 & 10 & 25.7 \\
\hline Disease knowledge & 39 & 9 & 23.1 & 20 & 51.3 & 10 & 25.7 \\
\hline Patient reaction to the diagnosis & 39 & 20 & 51.3 & 17 & 43.6 & 2 & 5.1 \\
\hline He informed about the disease & 39 & 4 & 10.3 & 18 & 46.1 & 17 & 43.6 \\
\hline Tuberculosis impact on life & 39 & 13 & 33.3 & 9 & 23.1 & 17 & 43.6 \\
\hline Tuberculosis impact on work & 39 & 28 & 71.8 & 5 & 12.8 & 6 & 15.4 \\
\hline \multicolumn{8}{|l|}{ Dimension 4 - Treatment } \\
\hline Treatment difficulties with drugs & 39 & 7 & 17.9 & 20 & 51.3 & 12 & 30.8 \\
\hline Difficulties in treatment in the course of the disease & 39 & 0 & 0 & 5 & 12.8 & 34 & 87.2 \\
\hline Difficulties in treatment in relation to family living & 39 & 6 & 15.4 & 2 & 5.1 & 31 & 79.5 \\
\hline Difficulties in treatment in relation to the support at work & $17^{1}$ & 9 & 52.9 & 2 & 11.8 & 6 & 35.3 \\
\hline Desire for withdrawal from the continuity of care & 39 & 4 & 10.3 & 8 & 20.5 & 27 & 69.2 \\
\hline Ability to formulate life projects to be implemented after treatmen & 39 & 3 & 7.7 & 28 & 71.8 & 8 & 20.5 \\
\hline
\end{tabular}

1 This marker was only answered by people who performed some labor activity at the time of data collection, the equivalent of 17 participants, so were not considered the 39 study participants.

Figure 1: Standard-box diagram for frequency distribution of the scores of individual and social vulnerability markers for accession to tuberculosis treatment. Campina Grande, Brazil, in 2015.

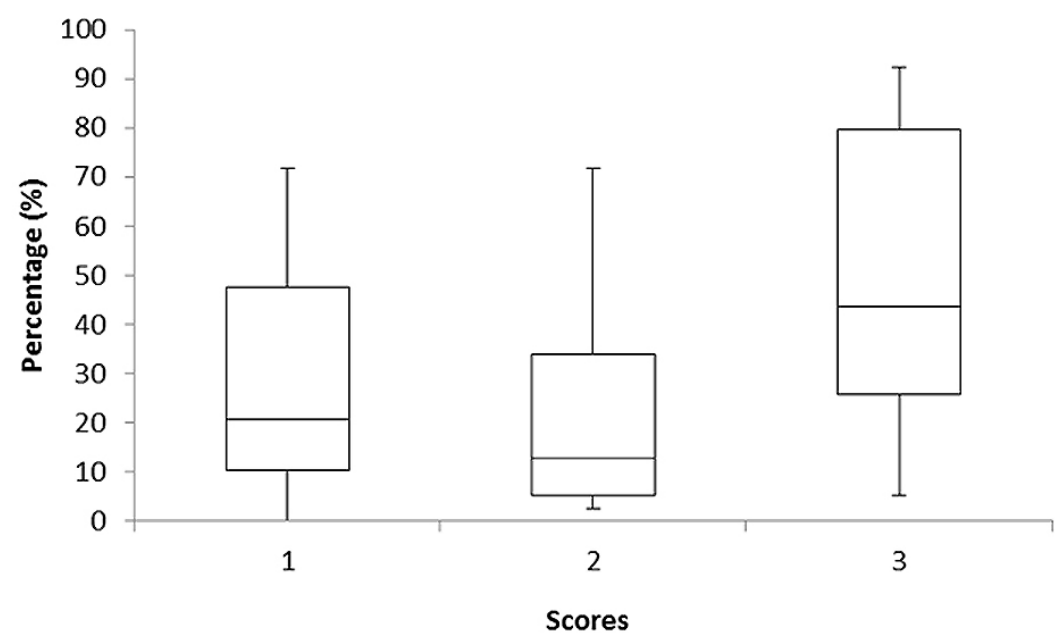


whom show higher vulnerability to adherence to TB treatment. However, it is also the score that had a wider range of data, with a quite considerable variation between the data (minimum of $5.1 \%$ and a maximum of $92.3 \%$ of responses).

The quantitative response by scoring one presents a median of $20.5 \%$ (equivalent to eight participants). The score number two have median of $12.8 \%$ (equivalent to five participants); both accounted for less vulnerability to adherence to TB treatment. It was revealed that scores number one and two had lower dispersion when they were compared to the score three and also have the same dispersion between data (minimum of $0 \%$ and a maximum of $69.2 \%$ and a minimum of $2.6 \%$ and a maximum of $71.8 \%$, respectively).

For the visualization of data in boxplots (Figure 1), it is observed that the score three is the one with greater dispersion of data (with the highest median and larger variations in values compared to other scores). The scores one and two were those who showed less dispersion (characterized by lower median, minor variations of values, and values closer to the minimum compared to score three). The visualization of data in boxplots charts gives an idea of position, dispersion, asymmetry and discrepancy of data. The center position is given by the median. An asymmetric distribution to the left can be seen, with values centered between approximately ten fifty.

\section{Discussion}

The confrontation capability of the disease is directly linked to accession with tuberculosis (TB) treatment, because the higher this potential, the more likely to join the anti-tuberculosis therapy. What translates this capability to join or not is the aspects of vulnerability to which the individual is exposed.

In this study, the markers that were more related to one scores, which indicated lower potential for adherence to TB treatment were: "TB impact on the work," "conception of causality of the health-disease process" and "work (employment status)".

Participants in this study said, in part, that the developing TB caused negative impact on their work activities, leading to a high percentage of a score. The score one was also high in considerable number of participants, who also said not working at the moment due to illness. Such statements were also found in other Brazilian studies [12, 16].

TB treatment often includes staying away from work [17]. This treatment involves going to appointments, making follow-up examinations and attend the supervision of medication doses, which can modify the daily life of patients and, on certain occasions, causes the person to lose job day to meet the commitments that the treatment of the disease requires [18].

It is considered that TB can have a negative effect on work when there are difficulties in carrying out such activities or when there is impossibility of performance of work tasks with the need for removal of the same, since most cases are linked to unwillingness to activities that require greater effort, involving breathing difficulty, which may result in wages or even layoffs, which may represent a significant reduction in family income [12, 18-19].

Such situation of being retired from labor activities may generate constraints for TB patients, because they realize that maybe they're being discriminated, and also this generate economic repercussions, becoming these sometimes the reasons for non-adherence to treatment. However, the recommendation o retirement must take the time that baciloscopy remains positive [17, 20], not justifying the employer's stance on wanting to ward off the ill worker of activities.

Another situation observed is when, after the expulsion and the worker's return, the resignation occurs, showing that what was behind it all is the prejudice linked to the transfer or to the stereotyped image of the TB patient [20]. 
Concomitant with the unemployed situation, participants mostly responded the ignorance to the causality of TB, with also high percentage of a score. Patients with TB often associate the disease to diffuse elements such as chill and consumption of cold drinks, demonstrating not sufficient information about TB, even during the treatment. The lack of information is still regarded as one of the main challenges for disease control [3, 21].

The TB misinformation can still make people confused about the disease's symptoms [22, 23], which raises the potential of late diagnosis and consequently hinders the treatment's adherence [24, 25].

Non-adherence to TB treatment is also often related to the low level of disease information, as factors from individual vulnerability associated to patients. Therefore, proper information for the patient significantly increases the probability of adherence by this [16, 26-29].

This context explains the individual and social vulnerabilities printed in precarious conditions of life and work, which interfere in access to resources, including health ones, and those which relate to information, which in turn can distance the patient from health services, making it more difficult to realize of TB treatment [8, 30-31].

In contrast, markers that were more closely related to the three scores that resonate with greater adherence capability to TB treatment were: drug use, life (housing situation) and difficulties in treatment in the course of the disease.

Regarding to drugs use, the participants mostly did not use those substances, which consisted of a very considerable point to enhance the adherence to TB treatment of the group studied, with high frequency of score three.

Adherence to TB treatment is considered difficult to predict, so that cannot be perceived as a static and linear process, but patients with problems such as alcoholism and/or drug abuse, as well as the homeless, are usually non-stick [8, 32].
Vulnerable situations, such as drug and alcohol problems, reveal the importance and necessity of health linkages with other sectors [33], mainly with services/associations engaged in the treatment of drug addiction and alcoholism, as well as the user's community and family members $[16,30]$.

The TB control, with regard to adherence to treatment of people who use illicit substances, becomes a challenge. However, recognition of drug use as a risk factor to the treatment by both the patient and the professional is a crucial point that, when considered and integrated with other care strategies to the patient, seeks to reduce dropout/ discontinuation rates of treatment and rehabilitation of health [16, 34].

Considering the "life" marker, regarding the housing situation, the majority of respondents lived with others in their home and none of them lived on streets, which may represent in this study a very favorable factor for accession, presenting a high score three frequency.

The importance of family involvement, living, health and housing conditions for users of the TB control program is known, to obtain success and not abandonment in the treatment [35]. The fact of people living in streets shows vulnerability to non-adherence and can interfere in successful TB treatment [36].

Considering the treatment difficulties in the disease course, a significant majority of respondents said that after the beginning of treatment, a significant clinical improvement showed up, representing high score three frequency. In this case, this factor was favorable to the greatest potential for accession, leading to the understanding that when people feel good with treatment and recognize the improvements, they are encouraged to continue.

Some users perceive the drug treatment as a positive point for accession, due to the signs and symptoms improvement, also considering supervision as something normal and favorable; at a time 
when they feel they are cared as they receive guidance on the treatment [8].

However, it is noted that due to remission of symptoms, other patients abandon the TB treatment at the beginning, which causes the agent to persist in the body, exposing the patient for recurrence and drug resistance. This clinical improvement in the first months of treatment is crucial for some patients because it may discourage the person to continue to therapy, as he thinks that he is cured [37-39].

In the study, markers related to work and conception of causality of the health-disease process represent important points to be leveraged, as presented expressive score one frequencies, related to negative impact of TB on life/work and ignorance about the disease. It is essential the better elaboration of these markers, in order to improve them and lift them to the conditions that determine the score three when the patient has steady work and recognizes the causality of health-disease process.

The challenge of confronting tuberculosis, both in the political as welfare areas, is to consider the importance of user context for successful treatment, providing resources that facilitate this process. Thus, those intersectional actions are essential that, although they may seem to escape the scope of "health, " being less practiced, promote the participation of society and the bond, and are prerequisites for the National Health System to work with quality required.

The instrument use was important to show markers with low potential vulnerability to adherence to tuberculosis treatment, showing which of them need intervention, as in the case of "tuberculosis impact on the work", "work (employment status)" and "conception of causality of the health-disease process", recommending the use of markers in Primary Health Care for monitoring adherence to tuberculosis treatment.

Markers that showed potential in favor of adherence to treatment of tuberculosis should be strengthened to keep this positive potential, like not using drugs, not live on the streets and not experience worsening of symptoms after the start of treatment.

You can see that the markers are linked, since they constitute situations of individual and social vulnerability, so that the improvement of them can bring about the improvement of other modifying a low status and/or medium to high vulnerability situation to adherence to tuberculosis treatment.

TB causes weakness and difficulties in performing daily activities such as work, causing social and economic losses to the patients and their families. Incentives and social protection measures for adherence to treatment and healing represent a potential strengthening. The vulnerabilities in individual and social dimensions represent wear for the accession process to the treatment.

\section{Competing interests}

The authors declare que They have no competing interests.

\section{Authors' contribution}

RCAT, FDTL, MRB and TMRMF participated in the acquisition of data and revision of the manuscript. RCAT, FDTL, TMRMF, SNBL, ELS, LCA and FLAF conceived the study, determined the design and interpreted the data. RCAT, FDTL, MRB and TMRMF drafted the manuscript. All authors read and end casette approval for the version submitted for publication. 


\section{References}

1. Brazil, Ministry of Health Secretariat of Health Surveillance.. And pidemiológico Bulletin. 2014; 44 (2): 1-13.

2. Brazil, Ministry of Health. Secretariat of Health Surveillance, Department of Epidemiological Surveillance. Epidemiological surveillance Guide. $6^{\text {th }}$ ed. Brasilia (DF): MS; 2005.

3. Brazil, Ministry of Health Secretariat of Health Surveillance Department of Epidemiological Surveillance... Manual of recommendations for the control of tuberculosis in Brazil. Brasilia: Ministry of Health, 2011.

4. Bertolozzi MR, Nichiata LYI, Takahashi RF, Ciosak SI, Hino P, Ferreira do Val L, et al. The vulnerability and the compliance in Collective Health. Rev Esc Enferm USP. 2009; 43 (ESP2): 1326-1330. DOI: http://dx.doi.org/10.1590/S008062342009000600031

5. Brazil, Ministry of Health Secretariat of Health Surveillance. Health Surveillance Guide - Brasilia: Ministry of Health., 2014. p.379-416.

6. World Health Organization. Adherence to Long-Term Therapies: Evidence for Action. Tuberculosis. Geneva: 2003.

7. Souza MSPL, SM Pereira, Marine JM, Barreto ML. Characteristics of health services associated with adherence to tuberculosis treatment. Rev. Public health. 2009; 43 (6): 997-1005. DOI: http://dx.doi.org/10.1590/S0034-89102009005000085

8. Queiroz EM, De-La-Torre-Ugarte-Guanilo MC, Ferreira KR, Bertolozzi MR. TB: limits and potential of supervised treatment. Rev. Latin Am. Nursing. 2012; 20 (2): 369-377. DOI: http://dx.doi.org/10.1590/S0104-11692012000200021.

9. Ayres JRCM, Paiva V, France Junior I. Concepts and practices of prevention: the natural history of the disease to the vulnerability framework and human rights In: Paiva V, Ayres JRCM, Buchalla CM. organizers. Vulnerability and Human Rights: prevention and health promotion - Book I: disease citizenship. ISBN: 978853623912-5. Curitiba: Juruá; 2012. p.71-94.

10. Ayres JRCM. Vulnerability and AIDS: For a social response to the epidemic. AIDS Bol Epidemiol. 1997; 15 (3): 2-4.

11. Ayres JRCM, Paiva V, France Junior I, Gravato N, R Lacerda, Della Negra $M$ et al. Vulnerability, human rights, and comprehensive health care needs of young people living with HIVIAIDS. Am J Public Health. 2006; 96 (6): 1001-1006. DOI: 10.2105/AJPH. 2004.060905.

12. Cavalcante EGR. Adhesion markers to tuberculosis treatment: a proposal to primary health care. University School of Nursing of São Paulo [PhD thesis]. São Paulo: Universidade de São Paulo; 2012.

13. Bertolozzi MR. Adherence to tuberculosis treatment: Implementation of markers for patient monitoring (MCT Notice/ CNPq No. 14/2013 - Universal, Range B). Project approved. Nursing USP. São Paulo, 2013.
14. Brazilian Institute of Geography and Statistics (IBGE) [homepage of the internet]. Brasilia: Ministry of Planning; 2013 [access 03 April 2015]. Available in: http://cidades.ibge.gov.br/xtras/uf.php ?lang $=$ \& coduf $=25 \&$ search $=$ paraiba

15. Secretariat of Campina Grande Health, Municipal Health Service, Tuberculosis Clinic. 2014

16. Passion LMM, Gontijo ED. Profile of notified tuberculosis cases and factors associated with abandonment, Belo Horizonte, MG. Rev Public Health. 2007; 41 (2): 205-213. DOI: http://dx.doi.org/10.1590/50034-89102007000200006.

17. SS Souza, Silva DMGV.. Passing through the experience of treatment for tuberculosis context text - Nurse. 2010; 19 (4): 636643. Available in: http://www.scielo.br/pdf/tce/v19n4/05.pdf

18. Needham DM, D Bowman, Foster SD, GodfreyFaussett P. Patient care seeking barriers and tuberculosis program reform: a qualitative study. Health Policy, 2004; 67 (1): 93-106. DOI: http://dx.doi.org/10.1016/S0168-8510(03)00065-4.

19. World Health Organization. Global TB control, surveillance, planning, financing. Geneva: WHO; 2005.

20. Pôrto A. Social representations of tuberculosis: stigma and prejudice. Rev. Public health. 2007; 41 (1): 43-49.

21. Lacerda SNB; Temoteo RCA; Figueiredo TMRM; Luna FDT; Sousa MAN; Abreu LC; Fonseca FLA. Individual and social vulnerabilities upon acquiring tuberculosis: a systematic literature review. International Archives of Medicine, 2014; 7 (35): 1-8. DOI: 10.1186/1755-7682-7-35

22. Machado ACFT, Steffen RE, Oxlade O, Menzies D, Kritski A, Trajman A. Factors associated with delayed diagnosis of pulmonary tuberculosis in the state of Rio de Janeiro. J. bras. pneumol. 2011; 37 (4): 512-520. DOI: http://dx.doi.org/10.1590/ S1806-37132011000400014.

23. Chimbanrai B, Fungladda W, Kaewkungwal J, Silachamroon U. Treatment-seeking behaviors and improvement in adherence to treatment regimen of tuberculosis patients using intensive triadmodel program, Thailand. Southeast Asian J Trop Med Public Health. 2008; 39 (3): 526-541.

24. Jorge de Souza KM, Villa TCS, Assolini EFF Beraldo AA, France A, Protti ST, et al.. Delay in diagnosis of tuberculosis in prisons: the experience of the patient convict context text - Nurse. 2012; 21 (1): 17-25. DOI: http://dx.doi.org/10.1590/ $\underline{\mathrm{S} 0104-07072012000100002}$.

25. Lafaiete RS, Souza FBA, Motta MCS. The delay in the diagnosis of tuberculosis. Journal of Primary Care Research On Line. 2013; 5 (3): 174-180. DOI: 10.9789/2175-5361.2013v5n3p174.

26. Storla DG, Yimer S, Bjune GA. A systematic review of delay in the diagnosis and treatment of tuberculosis. BMC Public Health. 2008; 14 (8): 15. DOI: 10.1186/1471-2458-8-15. 
27. Bergel FS, Gouveia, N. Frequent return as a novel strategy for adherence to tuberculosis treatment. Rev Saude Publica. 2005; 39 (6): 898-905. http://dx.doi.org/10.1590/S003489102005000600005 .

28. Bertazone EC, Gir E, M. Hayashida situations experienced by nursing staff in care for pulmonary tuberculosis. Rev Latino-am nursing. 2005; 13 (3): 374-381. DOI: http://dx.doi.org/10.1590/ S0104-11692005000300012.

29. S Ribeiro, Amado V, Camelier A, Fernandes MMA, Schenkman S. Case-control study of dropout indicators in patients with tuberculosis. J Peneumol. 2000; 26 (6): 291-296. DOl: http://dx.doi.org/10.1590/S0102-35862000000600004.

30. Queiroz EM, Bertolozzi MR. Tuberculosis: supervised treatment in the North Health Coordination, West and East of São Paulo. Rev ESC Enferm USP. 2010; 44 (2): 453-461. DOI: http://dx.doi.org/10.1590/S0080-62342010000200030.

31. Ayres JRCM, France-Junior I, Calazans GJ, Saletti Filho HC. The concept of vulnerability and health practices: new perspectives and challenges. In: Czeresnia D, Freitas CM, organizers. Health promotion: concepts, thoughts, trends. Rio de Janeiro: Fiocruz; 2003.

32. Vieira AA, Ribeiro SA. Adherence to tuberculosis treatment following the imposition of supervised treatment strategy in the municipality of Carapicuiba, São Paulo. J Bras Pneumol. 2011; 37 (2): 223-231. DOI: http://dx.doi.org/10.1590/S180637132011000200013.

33. Paz EPA, Sá AMM. The daily routine of patients in tuberculosis treatment in basic health care units: a phenomenological approach. Rev. Latin Am. Nursing. 2009; 17 (2): 180-186. DOI: http://dx.doi.org/10.1590/S0104-11692009000200007

34. Chirinos NEC, Meirelles BHS. Factors associated with abandonment of tuberculosis treatment: an integrative review. Text context - Nurse. 2011; 20 (3): 599-606. DOl: http://dx.doi.org/10.5123/S1679-49742013000100008

35. Oliveira MG, Silva CB, Lafaiete RS, Motta MCS, Villa TCS. The patient in TB treatment in Itaboraí, Rio de Janeiro -. Family involvement. Rev bras med fam community. 2011; 6 (18): 40-45. DOI: http://dx.doi.org/10.5712/rbmfc6(18)117.

36. Campani STA, Moreira JS, Tietbohel CN. Factors predictors of noncompliance with treatment for pulmonary tuberculosis recommended by the Ministry of Health of Brazil in Porto Alegre (RS). J. bras. pneumol. 2011; 37 (6): 776-782. DOI: http://dx.doi.org/10.1590/S1806-37132011000600011
37. Menzies R, Rocher I Vissandjee B. Factors associated with compliance in treatment of tuberculosis. Tuber Lung Dis. 1993; 74 (1): 32-7. Erratum in: Tuber Lung Dis. 1993; 74 (3): 217. DOI: 10.1016/0962-8479 (93) 90066-7

38. Christmas S, J Valente, Gerhardt G, ML Penna. Prediction model for abandoning the treatment of pulmonary tuberculosis. Bol Pneumol Sanit. 1999;7 (1): 65-78. Available in: http://scielo. iec.pa.gov.br/scielo.php?scfript=sci arttext\&pid=S0103460X1999000100007\&lng=pt.

39. Mendes AM, Fensterseifer LM. Tuberculosis because patients abandon treatment ?. Bull. Pneumol. Sanit. 2004; 12 (1): 25-36. Available in: http://scielo.iec.pa.gov.br/scielo.php?script=sci arttext\&pid=S0103-460X2004000100005\&lng=pt.

\section{Comment on this article:}

\section{(f) $[$ in $8+\boldsymbol{S}$ P}

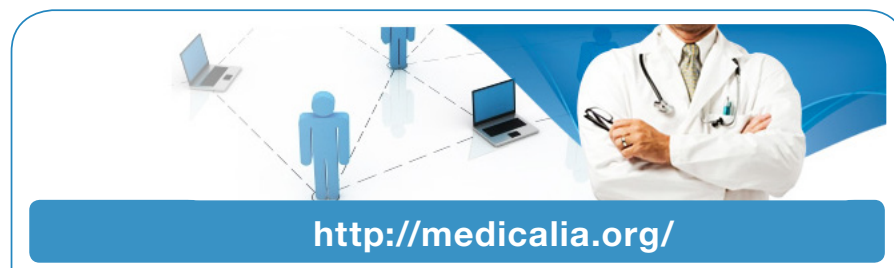

Where Doctors exchange clinical experiences, review their cases and share clinical knowledge. You can also access lots of medical publications for free. Join Now!

\section{Publish with iMedPub}

\section{http://www.imed.pub}

International Archives of Medicine is an open access journal publishing articles encompassing all aspects of medical science and clinical practice. IAM is considered a megajournal with independent sections on all areas of medicine. IAM is a really international journal with authors and board members from all around the world. The journal is widely indexed and classified Q1 in category Medicine. 